\title{
FOUCAULT'S BODY
}

\author{
"Ni mort ni vivant, non encore enterré mais 'sans oeuvre' -. le \\ magnifique mot de Foucault pour désigner la folie : disparu."
}

(Althusser 19)

Imagine a body, the body of the other lying in front of you. Through your perspective, by dint of your situation in the space you occupy, you have determined focus, gaze, vision. You have decided what is in your purview. Imagine that body neither alive nor dead, neither moving nor inert, defined neither as a corps nor as a corpse. Try to imagine it. It is someone, it belongs to someone, or perhaps it belonged to someone. To decide whose body it is, we must know if it is alive, if it is a subject, or the effect of a subject, or if it is purely and simply an object, just there, belonging to no one in particular. Belonging to someone else. Who does the body belong to when it is a corpse? It is an odd question, for in our time we think or believe that a human cannot belong to anyone else. We think or believe that the body is sovereign and specifically, that my body is mine. But when the corps becomes a corpse, we no longer know to whom it belongs. Is it, like some other inert chattel or object, the property of the inheritors, the legatees? Can one will one's body to be the property of another? Seemingly one can, and yet, no sooner belonging to someone else, the body is more often than not cast off, buried, burnt, discarded.

The body of an other is an object that one wants only as long as that other, defined as some sensate being inhabiting or imprisoned within that body, is still resident. Once that soul, being, or heart is gone, once that body is only a body, no one wants it. The remains of the other cannot be his or her body, cannot be a body belonging to someone else. Necrophiliacs beware: you want what is willed to an other which that other does not want. Your desire is false, aberrant, unseemly, inhuman, because you do not desire according to the law of desire: you desire what no one desires.

To think of the body before it is categorized as living or dead means to rethink or to unthink a whole set of categories. Just for a moment, eliminate the thorny question of the subject, if only because the body has no necessarily resident subject. Perhaps the subject is only an effect of a subject, as fleeting in one way as it is evanescent in another: when the body is reduced to being the absolute object to be traversed, crisscrossed, barred, imprisoned by the discourses, powers, and grids that fix it, when that body has become an absolute prisoner of solitary 
confinement, the effect of subject is gone.

So think then of the body neither living nor dead or both living and dead. Imagine that body, think of it in your mind. See it then before you. To see that body, to gaze on that body is to make it yours, to appropriate that body for yourself. Living or dead, that body becomes the object of your gaze, the object of your coveting gaze, the appropriated thing that you now possess. You have watched the body of the other, you have made it yours, rightly or wrongly, you have gazed upon it. To conceive of it is to look at it, to possess it with your eyes. You have assumed the sadistic position. In your mind, you do with it what you will.

Consider the position in which you stand to look at the patient, the position you take to decide who is sane and who is crazy, the position you assume to look at a painting of some ladies in waiting. You dominate with your gaze: lying there lifeless or squirming from the torturous look by which you control her or him with your vision, the other becomes subject(ed) to your thought, politics, action, and discourse. The discourse of power translated into and translating your gaze confirms you as the master of what you survey. But wait, for you too are in discourse, subject to the same language; you think you have the independence of a subject, the liberty or disponibilité of a free agent. Yet you are incapable of creating a position that is yours alone. Your mind and your body are subject to some other; you too are captive in a web or grid of discourse to which you are the tacitly assenting party. Wait again: what is at the center of what you see is not that subjected subject, captive of the grid. As you look into the center, you see yourself: you do not see the patient but the discourses you have proffered; you do not see the boy you love, subjected to your whims, but the logos describing what you can do, the same logos that you have appropriated for yourself (Usage 100-03). You do not see the redoubled reflection of something already there, but your own eyes, the eyes of the king that are now your eyes, the eyes of an absolute subject overcoming your own imprisonment by the returned reflection of your vision (Mots 24-25).

Look then as Foucault looks. Share the scene of the body (of another, of himself as other) that he puts before you, as if it were his to give. And then and only then, look at his body to see if you too have appropriated a position as I suggest. Foucault's study of the prison opens with what has become a famous description of the body of a condemned prisoner who in 1757 is put to death by being burned and then drawn and quartered (Surveiller 9). The public spectacle of torture, of supplice, the torture not to extract information, but the torture unto death, is a performance wherein the actor is always already the body that is neither 
living nor dead or both living and dead. Subject to the covetous view of the other, of all the others, the condemned prisoner is the figure of the common whore, belonging to all, subject to all possessive gazes, forced to go in every direction by the ones that have power over her or him. The body of the prisoner, usually male, is feminized by the power of the observer, sadistically and heterosexually male.

Not castration so much as the vision of a forced heterosexuality. To avoid the mimesis of the justly condemned homosexual position wherein the male looks at and possesses the corps, corpse of the male other, the prisoner becomes a woman, deprived of power, of phallic center, of an ability to move or to be. Sade--for his name has already appeared-is injudicious, obscene, improper in that he does not sublimate or disguise that homosexual position in a heterosexual mask.

The eighteenth century that Foucault chooses as one of his privileged objects of study knows that order must be maintained. The male subject can look; the female subject must either be subjected, looked at, or, on occasion, may look away. But in no way can she look. Plate 29 of Surveiller et punir is an engraving from the end of the eighteenth century. It features a steam-run machine for the "correction" of little girls and boys. It seems to have a set of "verges" and "fouets" that are used to spank the children as Mr. Croquemitaine and Mme Briquabrac supervise. Interestingly enough, the adult male looks on, whereas the adult female is facing away from the machine and the supplicating child.

The nineteenth century universalizes that male position of vision and gaze while removing the direct use of power involved in the supplice. Am I wrong to suggest that this position is still a sadistic one, still a sexually sadistic one, and still a homosexual one? To look at the prisoner without killing him, to make your gaze the universal eye watching the other is to desire according to the eyes of male vision, to make every position a homosexual sadistic one. René Girard, following Hegel, is right: if desire is effectuated according to the desire of another, i.e., if I as a male desire a woman, it is because another male already desires her. Thus for Girard, desire is fundamentally homosexual. If then, in the world of Foucauldian vision, I possess the other with my eyes, it is because I have imprisoned him in the structures of male dominance. The sodomy for which prisons are unjustly famous is a redundance of the homosexual possession that the other makes of the body of the prisoner.

Foucault speaks of nothing else. Whether it is the creation of the medical gaze as the corpus of symptoms is created, or the invention of man, whether it is the effect of the subject imprisoned in discourses of general knowledge or the actual imprisonment of the body in a cell into 
which the eyes of the other can always penetrate, the discourse of Foucault repeats endlessly that the universal position, at least from the nineteenth century on, is one that is both homosexual and sadistic. The body of the other becomes the mutilated corps or corpse of Saint Sebastian, gay icon par excellence: "During the classical era, there was a whole discovery of the body as the object and target cible] of power" (Surv. 138).

Foucault relates the transformation of the body as an object for penology in which the "body itself is invested with the relations of power" (28) to the concept of the "king's two bodies" developed by Ernst Kantorowitz. Specifically, Kantorowitz considers that in the body of the king, there is both the transitory element of the individual who is born and dies and the transcendent element of the king that remains throughout time. Similarly, Foucault suggests that the "condemned prisoner is marked as the symmetrical and inverse figure of the king " (33). Thus, Foucault suggests, along with the body itself, there is a double, an incorporeal "soul" produced by punishment. This soul, unlike the Christian soul, is the locus where knowledge and power meet, "the effect and instrument of a political anatomy" and the "prison of the body" (34).

We might consider this soul then as the heterosexual construct, the "effect of the subject" within the structures of a homosexual and sadistic model. If the subject constructed by the discourses of society is presumed on the surface to be a heterosexual one, it is only after the internalization of the discourses of dominance. That is to say, one can become a fictionally-free subject in this society of dominance and exchange by buying into the position of the discourses of power, by ingesting them, by internalizing them. One becomes a subject by eating the words of the father, by accepting that the consequences of the so-called Oedipal model of capitalism are accession to a position of power by homosexually ingesting the Other of power and by passing oneself off thereafter as heterosexual.

Imagine a body, the body of an author. The body silenced in a way, a gag in his mouth, so that, puppet of the discourses of power he silently repeats the discourses of the other as he stifles through the gag: "What matter who's speaking?" ("What Is an Author?" in Language 138). Bound and gagged, the author disappears behind the text, behind the effects of a subject created, forced at that spot to perform as if it were a subject. What better retreat from being forced into a position where not only one's tongue is tied, but also one's body, than to pretend that the very body is not there. With no body there, there is neither corps nor corpse. With no body there, the space marked by no subject and no victim seems the uniform space of asceticism. In Foucault's writing, what could be 
loosely termed an ascetic approach to writing takes the form of the disappearance of the writer from the text. This disappearance is double, not the single one that we would normally predict of the writer's consciousness. For it is also the author's body that disappears from the work. That body will come back with a bang toward the end of his life, as he realizes the fundamental importance of his body for his text. As Miller (261) notes, quoting Leo Bersani: "'There was something explosive about his fascination,' recalls Leo Bersani, 'I mean, the scene was fun--but it wasn't that much fun!' " But before his body appears, can there be any doubt that he has to make it appear from within the walls of a Piranesian cell: "And while I was doing this project, I noticed that it was not working out. An important problem remained: why had we made sexuality into a moral experience? So I locked myself up, abandoned everything I had written on the seventeenth century, and started to work my way back. .." ("The Return of Morality" in Politics 252).

It is thus understandable to find Foucault using a present tense that has a deictic component in the second volume of Histoire de la sexualité. Whereas the atemporal present, the habitual tense for scientific enquiry, is a commonplace, a temporal present is a rare occurrence in his writing. The presence of the present tense is not only as the traces of an enunciative presence of mind, but also that of the body of the author:

To say things quite schematically: we tend today to think that the
practices of pleasure, when they occur between two partners of the
same sex, relate to a desire whose structure is particular; but we admit-
-if we are "tolerant"--that this is not a reason to submit them to a
morality [morale], even less to legislation, different from the one
common to everyone. The point of our interrogation, we bring it to
bear on the singularity of a desire that is not addressed to the other
sex; and at the same time, we affirm that one must not accord to this
type of relations the least value, nor reserve for it a particular status.

(Usage 212-13).

No body, dead or alive, flayed or left whole, occupies the phantom locus. No subjection to the dualism of Christian and capitalist order need interfere with the production of text or the realization of power grids. Dualism disappears, as does the division of soul and body, for without a body, the soul has no home. In L'Usage des plaisirs (74), Foucault contrasts Christian interiority with classical exteriority. Both imply a process of self-correction and self-work, but from vastly different perspectives. In Christian interiority, there is a "particular mode of relation to oneself that includes precise forms of attention, suspicion, déchiffrement, verbalization, admission [aveu], self-accusation, struggle 
against temptation, renunciation, spiritual combat, etc." (74). But the exteriority of classical moral relates to a set of external rules observed and followed, though without any interiorization of those rules.

And yet there is a body. At least a body is projected as a fantasy at the locus of the all commanding, sadistic other: "I believe the great fantasy is the idea of a social body constituted by the universality of wills" ("Body/Power" in Power 55). There must be a body, but that universal body is a fantasy. It is the projection of some single position, some single sadistic other; it exists; Foucault knows it; is it any wonder then that the body of the subject returns? For the sadistic position to function, it requires fodder, meat, a body on which to operate.

No, perhaps the ascetic position is better, a position without a body: "Yet a fact is there: in a few dozen years what disappeared was the tortured, dismembered, amputated body, symbolically marked on the face or shoulder, exposed live or dead, given in spectacle" (Surveiller 14). No body is on stage on which to operate, no body need be present behind the words of the discourse that insists on the neutrality of its position, I would say, the singular neutrality of its position. Neither masculine nor feminine, neither heterosexual nor homosexual, the transmitter of discourse does not have to decide for himself, can eclipse himself from the stage, as observer and body alike disappear. If there is no body to punish, if there is no observer to categorize, the neutral disembodied observer can move from focusing on the repressive effects of discourse to seeing a series of positive effects (Surveiller 28). Neutrality means that one does not have to say, decide, or be, one can be moved off one's invisible mark, neither presence nor absence, neither alive nor dead. And that any movement, in any direction is a positive step.

Not saying one is gay, not having to say one is gay, pretending, not that one is not gay, but that that position can be a neutral one, this is the ascetic ideal in text. Or at least in some texts, for in Foucault's writing, there is both the espousal of a position of neutrality and, in select spots, a presentation of the position of a gay individual different from the scientific, neutral position often seen in the writing. There are two possibilities then. The first is that the position of the individual caught in discourse and transmitting that discourse can be neutral, and that, specifically, the definition assigned by the general episteme to the genders of knowledge can be easily evacuated. In other words, there seems to be a belief in much of Foucault's writing that the marked position of transmitter of knowledge, which is white, male, heterosexual, can easily be neutralized.

But there is another position, a position that allows that the sexual 
position is an irreducible one, that despite all the sense of the social structuring of the sexual position, there is an irreducible mark or moment that cannot be (a)voided. The gay position is always there, not as a variant of the heterosexual position, not as an opposition to it, but as a difference from it. And it follows then that the neutral position constructed at the point of discourse is necessarily different from the other neutral position, the evacuated heterosexual position. That neither then is truly neutral and is always marked by the gendered, sexual signs of discourse and behavior remains eminently clear as well. To be gay is to realize that there is another history, another discourse that is not so easily neutralized.

It also means that there are perhaps two versions of the same history, for example, the history of homosexuality, two versions of the same social construction, that do not necessarily correspond except in their surface phenomena. Take for example, the tentative, neutral, dispassionate, scientific description of pederasty, the love of boys that comes to the fore in the second and third volumes of L'Histoire de la sexualité. Now in part, Foucault needs to deal with what amounts to one of the great taboos of the contemporary Western world. And at least implicitly, the movement from exteriority to interiority brings about the complete repression of the possibility of the love for boys. Yet if Foucault's model and epistemological system are correct, the so-called repression of the love of boys, the construction of a taboo is not part of a repression per se but actually a means of channeling that same structure of desire. Hence Foucault's discussion of the love of boys must proceed delicately in order not to seem to be shaking the foundations of the taboo.

Now I would hypothesize that the fundamental ambiguity at the heart of Foucault's work relates to this sexual question. And we must ask ourselves how that ambiguity plays itself out. Does, for example, the fact that Foucault is gay have importance for how we read the text? Some would say that it has everything to do with it. On the other hand, some would say that while perhaps anecdotally interesting, Foucault's homosexuality in and of itself does not have much of an influence. Foucault's position could be described as the absence of heterosexuality, it could be explained as being different from heterosexuality. But it could also be articulated as that from which a heterosexual position is different. A slight rhetorical move perhaps, but an important one. It matters what is defined first. The question is not "What matter who's talking?" but "What matter who talks first?" More precisely, if homosexuality is never defined as secondary to heterosexuality, then our perspective on the whole matter changes considerably.

In his biography of Foucault, Didier Eribon seems to consider 
implicitly or explicitly that the world of the reader is defined as being heterosexual, or at least that heterosexuality is the benchmark by which we read. As late as 1989, Eribon (12) is hedging his bet by saying that he envisages a general public for whom there is a "scandal still constituted today by the evocation of homosexuality." Eribon conceives of two possible sets of readers, those who might feel that he has said too much about the subject of homosexuality and those who regret "the absence of details or picturesque descriptions, on American life, for example" (12). He allows that he is more sympathetic to the latter, but that he does not want to shock the former. And it is this so-called American life, with its implicit freedom, abandon, and even danger that Eribon evokes at the end of the book as well: "Foucault's American happiness: the reconciliation with himself finally realized. He is happy in his work. He is happy in the pleasures of the body.... But it is precisely there that the new plague was beginning to spread out its odious ravages" (338).

It is not at all "American life" on which the details are lacking, but rather "Foucault's gay life." Understandably so, from a legal point of view, for going much beyond the simple statement of fact could possibly have led to a libel suit against Eribon, since it would seem that it is in fact defamatory to go into detail about an individual's homosexuality. Though not subject to the same libel laws, Miller announces the same lack of information: "What exactly Foucault did in San Francisco in the fall of 1983--and why--may never be known" (29). We shall return to the dangerous implications of this black box of non-knowledge below.

Eribon's position is a safe one. He discusses Foucault's homosexuality from the point of view of the dispassionate, yet sympathetic reader who has adopted a view that sees the normative heterosexual position as the central one. Foucault's homosexuality must be understood as different from what is accepted by the dominant discourse, and when it is just one mode among others, it is not worth mentioning:

[...]I decided to tell the facts, in their reality, when they had to be told to understand such and such an event, such and such an aspect of the career, work, thought, life--death--of Foucault. I passed over them silently when they concerned only the secret territory that each and every person arranges in his own existence.

So we could say that from the outset, Eribon's position seems unconsciously to mime the dualistic one that Foucault has set out for himself. On the one hand, there is a gay body, undeniably there, at the center of the crossroads. The effect of the subject produces the gay body because it is perceived as such, and swathes it in a set of discourses that 
define it as the gay body. On the other hand, there are times when, from the point of view of the dominant discourse, there is no need to mention the question of being gay, for it is restricted to a secret territory.

Where is this secret territory? Is it some recess of the mind safe from the dominant discourses that form the effect of the subject, that determine when and where something like a subject will come into place? One would think then that the secret territory is some area, some imprisoned area safe from and impervious to the discourses of dominance. Where does this territory speak? Does it have its own language? And yet, even that Foucauldian impossibility seems to pale in comparison to the more general question of universality: every one of us has such a territory. If this is a universal, not only is there a set of discrete idioms and praxes relating to that territory, but moreover that territory is part of a universal set. We are all sexual beings, Eribon seems to be saying, regardless of the homo- or hetero- twist to the particular individual.

Despite the secret yet universal nature of the territory, there is a name for it, and Eribon spells the name out of that territory in the very first pages: America. Yes, in fact, it is the description of the picturesque aspects of American life that is missing for Eribon, because America is the fulfillment of the pleasure principle:

For Michel Foucault, the United States is the pleasure of work. But it is also just pleasure. He tastes the liberty that exists in New York or in an Francisco, with their homosexual neighborhoods, where there is a flowering of magazines and newspapers, bars, and nightclubs... The gay community is uncountable, organized, and firmly decided to impose its rights. And also--this is not without importance--, the United States is a country where homosexuality is not marked by an age limit, by the severely defined criteria of youth.

Thus one version of the story presents an idealized exteriorizing of an America where everything is possible, where there is a freeplay of sexual choices and sexual acts. It is an America that beckons, like a gay utopian paradise in which all acts somehow are possible, in which new games and new pleasures await. America is the pleasurable territory in which the body is not subjected to the arrest of discourse, where there is a flow of energies that is both a testament to an act of sexual liberation and a will to power. Certainly, as Lawrence Kritzman points out in his introduction to his collection Politics, Philosophy, Culture, commenting on Foucault's concept of homosexuality:

Gay sexuality is to be thought of as a dynamic mode in which the refusal of a more traditional lifestyle emanates from a sexual choice 
that transforms one's own mode of being; sexuality should be used to experiment, to invent new relations in which desire is problematized in a world of polymorphous perversions. For according to Foucault the ideology of sexual liberation is just another disciplinary technique for transforming sex into discourse and the homosexual into a species with a particular mode of life.

(xxiii)

Homosexuality is and is not choice; is and is not a category into which one is thrust. The ideology of sexual liberation so necessary for the liberation to take place is just one more structure of discourses from which the individual never escapes, forced as he is then to be an "out" homosexual, constrained--Sartre would say "condemned"--to his freedom.

Just as there are two visions of the body in Foucault, an alternation between the subjected body and the absent body, there are two visions of homosexuality. One is the fruit of constraint, even if that constraint is named "liberation" and "understanding." The second vision is one of choice and option, freedom as opposed to liberation. The first vision depends on a heterocentric point of view, a sustained position that sees homosexual behavior as an acceptable (or not) variant of a dominant sexuality. Its main difference from heterosexuality, in fact, its unique difference from heterosexuality, is in the choice of the anatomy of the sexual partner. This is certainly the point of view that Eribon adopts for much of his book, because it is one that seems to reflect a certain strain in Foucault as an individual.

As a difference, as a variant, however, it is ultimately problematic, for the possibilities allowed it within the power grid of discourses limit it, constrain it far more than heterosexuality: there are far fewer acceptable modes of presentation, behavior, ostentation for the homosexual individual than for the heterosexual one. The homosexual individual has society against him or her: even if society allows him or her to practice his or her behavior, accepts it, the acceptance takes place from within the stronghold of heterosexism. It is an acceptance that the heterosexual never has to face for himself or herself, for he or she is that sexual object defined by society as identical to its dominant vision. When heterosexual discourse looks in, it sees a reflection of itself. For all others, at least for homosexuals, there is a crisis. The crisis has a name in current gender studies circles: internalized homophobia. It used to be called "sensitivity." The gay individual internalizes the discourses of dominance and reacts to them, undergoing a crisis that the straight individual has no part of. So the gay adolescent or young adult, seeking his or her confirmation, is particularly susceptible to such a situation. Eribon (44) mentions Foucault's homosexuality when he was at the Ecole Normale Supérieure: 
"And in fact, when he returns from his frequent nocturnal expeditions in cruising spots or homosexual bars, Foucault remains prostrate for hours, sick, annihilated by shame." James Miller concurs. For him, the homosexual's life, often as not, is marked by a series of "seif-destructive" behaviors that are symptoms of the internalized discourses of control that have entered the very being of the gay individual who cannot see himself or herself except as that figure constructed by straight discourse. Miller (90) writes, for example, of Foucault and his lover that they "balanced their shared moments of Dionysian abandon through alcohol and sadomasochistic eroticism with their shared interest in unity and form."

Both Eribon's Foucault and Miller's Foucault are figures caught in a teleology of self-liberation. Miller's figure starts early: "Foucault as a young man made one small but telling gesture of revenge: in an act of self-assertion -- and nominal self-mutilation -- aimed directly at the bullying patriarch, Paul-Michel chopped off his nom du perre, becoming simply 'Michel Foucault'" (63). As he goes through life, this Foucault, interested more and more in the discourses of power, seeks simultaneously to liberate himself from these constrictions and structures of power that imprison him behind a mask. For example, as Miller notes, in 1969,

He had changed his physical appearance as well: while living in
Tunisia, he had Daniel Defert shave off all of his hair, which left him
with a skull that gleamed like a spearhead. With his wire-rimmed
glasses and smile of ivory and gold, he now looked faintly sadistic, like
a bullying field marshal: for years, the London Review of Books
would use his familiar image in advertisements ordering its readers to
subscribe.

So Miller's Foucault, involved in a process of self-liberation, exchanges one mask for another, seeks to find himself, to discover who he is through pushing the taboos and limits of the discourse that constrains him, by pushing back or crossing the barriers at the edge of experience. Miller (7) remarks early on that he "was forced to ascribe to Foucault a persistent and purposeful self, inhabiting one and the same body throughout his mortal life, more or less consistently accounting for his actions and attitudes to others as well as to himself, and understanding his life as a teleologically structured quest (or, in French, recherche)."

The second vision of homosexuality, one that involves choice, appears in the various interviews Foucault gave relating to homosexuality. In a sense, it also is the other face of Miller's view of Foucault: a Foucault who seeks to enact his own self, who wants $z u$ sich selbst kommen, a Foucault who recognizes his difference and seeks to bring that difference 
to life and to light. It is that same Foucault with a purpose, but the focus is changed: it is not a movement of self-liberation, but one of selfactualization, what Ed Cohen (91) calls both a space of possibility and of creativity. As Kritzman states in his introduction to his volume of Foucault interviews, "Through his many articles and interviews Foucault supported, although never quite militantly, the imperatives of the gay movement which, like other experiences such as drugs and communes, situated the individual on the threshold of other forms of consciousness and inscribed him in the 'culture of the self' (xxii). The key word is "other."

How so? The two visions of Foucault's concept of homosexuality seem to fall under the same general category of gay liberation. But there is a difference, I think, in emphasis, and in consequence. In the first, there is a process of liberation, of crossing of boundaries, and, ultimately, as we shall see below, the implicit idea of reaching limits and crossing them. In the second, the emphasis is elsewhere, on a distinct otherness, whose limits are not at all the same as the ones imposed on "sexuality"from the point of view, from the position of dominant, normalized, vanilla sexuality. As we shall see, in the second view, S/M behavior is not at all a limit or an extreme.

In the interviews, given to various journalists and other writers during the last decade of his life, Foucault provocatively formulates the concept of a distinct gay subject. In "Friendship as a Way of Life," Foucault discusses homosexuality with an interviewer for Gai Pied. Foucault says:

\footnotetext{
The problem is not to discover in oneself the truth of sex but rather to use sexuality henceforth to arrive at a multiplicity of relationships. And no doubt that's the real reason why homosexuality is not a form of desire but something desirable. Therefore we have to work at becoming homosexuals and not be obstinate in recognizing that we are. The development towards which the problem of homosexuality tends is the one of friendship.

(Live 204)
}

So the two imperatives, the two views of homosexuality are simultaneously there. As something desirable, homosexuality is a goal, an object to be attained; as something that "weare," it is not homosexuality that is the goal as such, but the removal of obstinacy, the negation of all the impositions on the subject, all the constraints that are placed on him or her. It is understandable that the two views are linked, for there is no utopia, or seems to be no utopia, except the envisioned America as pleasure-palace, where the two worlds do not collide. Yet in order to understand homosexuality as such, Foucault insists that we think from within it, and 
not merely as we approach it. It is at that point that the separateness of homosexuality comes through, the multiplicity of difference and the multiplicity of different desires that are unmarked by the imposition of heterosexual models and values. As he notes in the same interview on friendship, "What we must work on, it seems to me, is not so much to liberate our desires but to make ourselves infinitely more susceptible to pleasure. We must escape and help others escape the two ready-made formulas of the pure sexual encounter and the lovers' fusion of identities" (Live 206).

For Foucault, the problem of homosexuality is not the sexual act itself, but the possibility that this sexual act is not a self-contained unit, but something with a consequence: the result being the formation of lines of order, power, and communication distinct from those of society at large:

One of the concessions one makes to others is not to present
homosexuality as a kind of immediate pleasure, of two young men
meeting in the street, seducing each other with a look, grabbing each
other's asses and getting each other off in a quarter of an hour. There
you have a kind of neat image of homosexuality without any possibility
of generating unease, and for two reasons: it responds to the
reassuring canon of beauty and it annuls everything that can be
uncomfortable in affection, tendemess, friendship, fidelity, camaraderie
and companionship, things which our rather sanitized society can't
allow a place for without fearing the formation of new alliances and
the tying together of unforeseen lines of force. I think that's what
makes homosexuality "disturbing": the homosexual mode of life much
more than the sexual act itself.
(Live 205)

The consequences of this homosexual mode of life are clear: if the sexual act is not only an isolated, immediate act (though, of course, it can be), but some action with consequences for power, organization, and discourses, it stands to reason that even that sexual act, when found in a new set of contexts--that of the "homosexual mode of life"--means something else. In the vulgar sense, the sexual organs and orifices that heterosexual discourses define as those of homosexual intercourse are not the same as those defined by a homosexual power structure. From a Foucauidian point of view, contextual here as elsewhere, the penis and $a$ fortiori, the anus, defined by homosexual discourse as the organs of its sexual acts take on new values and new constraints. For Foucault, this difference already makes the penis and the anus "other." They are not the same sexual organs as they once were, just as, for example, the mad are not the same as they once were, or the sick, or the condemned, and so forth. 
It is clear that it is a short step from this position of homosexual sex to Foucault's concept of S/M. Obviously, Foucault's idea of S/M is wholly distinct from some pathology of sexuality. If there is an inspiration it is perhaps literary, but in the most banal sense: the idea of $S / M$ is its multiplicity and in the control of that multiplicity by the sadistic self: Asked about his interest in Sade in an interview conducted in 1973 entitled "An Historian of Culture" (Live 82), Foucault says, "It is evident that if I want to make love (or rather, when I want to make love) I do not resort to Sade's prescribed methods, to his combinations; not so much because I wouldn't like to try, but because I've never had the opportunity."

I would say then that the sadistic self meeting the sense of homosexuality that Foucault sees in the freedom (as opposed, once again, to the act of liberation of some imaginary) finds the extension of gay sexuality to some multiplicity the most natural consequence:

\footnotetext{
$S \& M$ is not a relationship between he (or she) who suffers and he (or she) who inflicts suffering, but between the master and the one on whom he exercises his mastery. What interests the practitioners of $S$ $\& M$ is that the relationship is at the same time regulated and open. ... This mixture of rules and openness has the effect of intensifying sexual relations by introducing a perpetual novelty, a perpetual tension and a perpetual uncertainty which the simple consummation of the act lacks. The idea is also to make use of every part of the body as a sexual instrument.

("Sexual Choice" 20)
}

For Foucault then, S/M, sado-masochism is misnamed. It is a question of two (or more) sadistic subjects, two individuals who both control a sexual situation. It is as far as possible from the game of dominance and submission traditionally associated with heterosexual intercourse. For Foucault, again in the vulgar sense, to take it up the ass is as sadistic a sexual action as another. Perhaps the most sadistic, for symbolically it is the enclosure of the organ of power, the capturing of the phallic penis, the imprisonment of the violent within a larger, yet controlled violence, yet with no will to reproduce the self in the realm of the imaginary as in heterosexual coitus.

If we turn then to Miller's vision of Foucault's S/M sexuality, and his patient explanation of that behavior, we wonder at the limited vision that this explanation implies. Miller explains in great detail, for example, the details of S/M behavior. Miller (264-65) gives the list of S/M techniques as he finds the catch-all "etc.' of Larry Townshend's book The Leatherman's Handbook, "the most widely read gay S/M manual, " woefully inadequate: "gagging, piercing, cutting, hanging, electric-shocking, stretching on racks, imprisoning, branding, blindfolding, mummifying, 
pissing on, shitting on, shaving, burning, crucifying, suspending, clamping, suffocating, fist-fucking." Following Geoff Mains in Urban Aboriginals, Miller (265-67) explains each activity in detail and adds that $S / M$ is not necessarily a sexual activity whose ultimate goal is orgasm.

But is this Foucault's S/M sexuality? Is it Foucault's sadism? I think not. To detail these activities is to give in too easily to a nomothetically defined sexuality that accepts the definitions of sexual behavior offered by dominant heterosexual discourse, to see homosexuality, perhaps as an acceptable variant, but to see $\mathbf{S} / \mathbf{M}$ as an extreme. No. I think for Foucault, S/M, at least as it appears to function for him as an eroticizing of the entire body is the most normal sexuality imaginable. For it is only in a world that puts logical and discursive chains on a discourse that sex becomes focused on a discrete set of genitalia, some of which are acceptable for use when coupled with others, some of which are not. But why do I say discourse? Because, in the world wherein we all live, Foucault included, S/M has to be discourse: it cannot go to the logical conclusion that Sade implies in his text of sacrificing a person for jouissance, of making a corpse from a corps.

Sade makes (it with) a dead body. Could Foucault, the voices ask, have gone as far? It is tempting to fall into an easily laid trap and think that the extreme sexuality that $S / M$ represents to the "normal" lay reader means a complete violation of ethical norms, of the human condition, of the social contract. Violation of one set of norms means perhaps that others were violated. Listen to Miller's repetition of the innuendoes. Miller's postscript deals with the rumor that Foucault, in full knowledge of his being sick with AIDS "had gone to gay bathhouses in America, and deliberately tried to infect other people with the disease" (375). He continues, for the explanation seems to make some sense to him: "I was immediately struck by the fact that the stories were leading me to pay attention to aspects of Foucault's style and historical argument that I had previously ignored" (376). And then a final hint, rhetorically put: "I now had to wonder whether the rumor that had gotten me started was closer to the truth than I had come to think possible" (381). Yet it concludes that this was not humanly possible. Foucault could not have knowingly done this, not because of some philosophical truth about Foucault, but because Foucault just was not sure if he had AIDS:

Everything that I had learned, from Defert and others, persuaded me that it was highly unlikely that Foucault would (as the rumor depicted him) go around deliberately trying to infect--and hence, in effect, murder--innocent people. Evidently he had been uncertain, perhaps to the day he died, whether or not he actually had AIDS.

(381) 
To me such a comment, such an exculpation begs the question. Before Miller, Eribon also put Foucault's knowledge of his own illness into question, only to come down on the side of knowledge: "Foucault knew. And did not want to know: in his diary, in November, 1983, he noted, according to Paul Veyne, who was able to read it after Foucault's death: 'I know I have AIDS, but my hysteria permits me to forget it' "(348). For Eribon, then, going on second hand evidence, Foucault knew he had AIDS; Miller writing later is not so sure. So Miller ultimately clears Foucault because the latter may not have known if he had AIDS. Thus, Foucault could have continued to have the same sexual encounters as he had previously had, and though sick, ignorant of that fact: he thus could not have knowingly infected someone else.

All that is well and good. But what if Eribon is right? What if Foucault knew he had AIDS? Did he then go around and "murder innocent people"? Inconceivable, hard to envisage even for a moment, unless of course we fall into the same old trap of thinking his sexuality as an extreme. Yes, he discovered this S/M sexuality over a period of time when he was a mature adult. But no, this S/M sexuality does not imply a breaking of all the rules. In fact, as I have said, for Foucault, this S/M sexuality, ultimately occurs in discourses and etiquette (rules of behavior). It is not translated into a simplistic game of power, whereby the sadist has a life or death control over the imprisoned masochistic other. No, for Foucault, it is a game for two sadists to play; to cheapen it by turning it into a game wherein one controls the true destiny of the other would be to repeat the unfortunate structures of power that Foucault had long sought to combat. To think that Foucault, like some child lashing out, willinglybrought the others down with him, is to forget Foucault's lessons, Foucault's thought, Foucault's beliefs from one end of his writing to another. Foucault may very well have been the "postmodernist sphinx" that Miller (320) believes him to be, but he was a sphinx always already faced with Oedipus, two sadists caught in a dance and game played among friends:

Homosexuality is an historic occasion to re-open affective and
relational virtualities, not so much through the intrinsic qualities of the
homosexual, but due to the biases against the position he occupies; in
a certain sense diagonal lines that he can trace in the social fabric
permit him to make these virtualities visible.
(Live 207)

Of course, as Miller says, one can never say for sure. But I would add: "of the man Foucault." Of the philosopher, I think that we can be certain that he did not willinglykill the object he loved. 


\section{WORKS CITED}

Althusser, Louis. L'avenir dure longtemps. Suivi de Les faits. Autobiographies. Paris: Stock I IMEC, 1992

Cohen, Ed. "Foucauldian necrologies: 'gay" politics'? politically gay?" Textual Practice 2:1 (1988), pp. 87-101.

Eribon, Didier. Michel Foucault. Paris: Flammarion, 1989.

Foucault, Michel. "Des caresses d'homme considérées comme un art." Libération (1 juin 1982), p.27.

-.-. Foucault Live. Ed. Sylvère Lotringer. New York: Semiotext(e), 1989.

.... Histoire de la sexualite 2. L'Usage des plaisirs. Paris: Gallimard, 1984.

..-. Language, Counter-Memory, Practice: Selected Essays and Interviews. Ed. Donald F. Bouchard. Ithaca: Comell University Press, 1977.

-.-. Les Mots et les choses: une archéologie des sciences humaines. Paris: Gallimard, 1966.

-.-. "L'homosexualité dans l'antiquite." Interview with J.P. Joecker, A. Sanzio, and M. Ouerd, Masques 13 (1982), pp. 15-24.

---. "Non aux compromis." Interview with R. Surzur. Gai Pied 43 (1982), p. 9.

..-. Politics, Philosophy, Culture: Interviews and Other Writings 1977-1984. Ed. Lawrence D. Kritzman. New York: Routledge, 1988.

--.. "Sexual Choice, Sexual Act: An Interview with Michel Foucault." Interviewer James O'Higgins. Salmagundi 58-59 (1982-83), pp. 10-24.

-.-. "Sexuality and Solitude: an Interview with Richard Sennett." London Review of Books 21 May - 3 June 1981), pp. 3-7.

-.-. Surveiller et punir. Naissance de la prison. Paris: Gallimard, 1975.

-... "Un plaisir si simple." Gai Pied 1 (1979).

---. Power / Knowledge: selected Interview \& Other Writings 1972-1977. Edited by Colin Gordon. New York: Pantheon, 1980.

Miller, James. The Passion of Michel Foucault. New York: Simon and Schuster, 1993. 